\title{
Principal self-government and subjectification: the exercise of principal autonomy in the Western Australian Independent Public Schools programme
}

\section{Brad Gobby}

\begin{abstract}
The launch of the Independent Public Schools (IPS) programme in Western Australia (WA) in 2010 reflects the neoliberal policy discourse of decentralisation and school selfmanagement sweeping across many of the world's education systems. IPS provides WA state school principals with decision-making authority in a range of areas, including the employment of staff and managing school budgets. Using an analytical toolkit provided by Michel Foucault and Foucauldian scholarship, this article examines how the IPS programme functions as a regime of government and self-government. Data collected from two IPS principals is used to examine the subjective effects of power as it is exercised in the IPS regime. The article finds that the IPS initiative introduces new possibilities for principals to actively participate in practices of self-formation, through which these principals self-steer, exercise their freedom and govern themselves and their schools. It illustrates how governmental mechanisms depend on, harness and shape the autonomy of these principals, and how their individual practices of self-government align with neoliberal governmentalities.
\end{abstract}

Keywords: governmentality; Independent Public Schools; neoliberalism; school principals; self-management

\section{Introduction}

In August 2009 in Western Australia (WA), the Liberal National Coalition government launched its election policy to provide principals with increased autonomy from the education bureaucracy. Termed the Independent Public Schools (IPS) initiative, the programme gives public schools the opportunity to apply for a range of authorities ('flexibilities') hitherto the responsibility of the Department of Education (DOE), including the authority to employ staff, to determine a school's staffing profile, to manage resources and a one-line budget, and to opt out of some DOE policies. Advocates of the initiative claim IPS empowers schools by giving them greater autonomy and independence from the education bureaucracy (Department of Education [DOE], 2010; Government Media Office, 2009). Although principals of IP schools would not be truly autonomous or independent, the opportunity to self-manage schools as small enterprises free from the putative 'suffocating red tape' (Government Media Office, 2009) of the education bureaucracy has been so appealing that nearly half of WA state school principals have applied for IPS status.

The social and educational discourses that frame reform movements such as IPS are neither neutral nor natural despite their portrayal as self-evident, reasonable or warranted. It is important that the normalising knowledges and practices shaping current reforms in education are investigated (Popkewitz \& Brennan, 1998). The discourses of autonomy and choice associated with neoliberal reforms to the governance of schools, such as the IPS programme, have been a matter of long-standing public concern, with the effects of neoliberal reforms on school-level practices being well documented (Ball, 2006, 2007; Campbell, Proctor, \& Sherington, 2009; Gewirtz, 2002; Niesche, 2012; Reay, 1998; Whitty, 
Power, \& Halpin, 1998). The IPS reform in WA is drawn from the same policy trajectory of school autonomy and self-management examined in those studies, and it too deserves to be investigated. The need for this examination is even more pertinent because the Australian Federal Government and the New South Wales and Queensland State Governments are now trialling and implementing similar initiatives. To shed further light on the nature of these neoliberal transformations, this article uses a Foucauldian theoretical lens to examine interview data collected from two principals whose schools have become IP schools.

Foucauldian studies into discipline, the subject and governmentality (Burchell, Gordon, \& Miller, 1991; Dean, 1999; Foucault, 1977, 1997, 2007, 2008; Rose, 1999) have been influential in the field of education studies. Many scholars have employed a Foucauldian theoretical lens to examine the neoliberal discourses that frame contemporary educational reforms, and consequently have offered ways to rethink the politics of education reform (Ball, MacGuire, \& Braun, 2012; Popkewitz, 1996, 2000). Some of this literature has been concerned with the individualising effect of relations of power, and the way disciplinary practices render teachers and principals into certain kinds of subjects. It has been argued, for instance, that when it comes to the production of subjectivities through multiple institutional practices in the educational arena, the enterprising, problem-solving, autonomous chooser is one contemporary formation of power (Peters, Marshall, \& Fitzsimons, 2000; Popkewitz, 1996, 2000). This article adds to this growing body of literature that acknowledges that subjectivity is central to governing populations through individuals. Using Foucault's notions of discipline, power and government, this article examines the practices of self-government and self-formation that principals engage in under the IPS regime. Such an examination highlights the operation of power through the formation of subjectivity in such reforms.

This article begins with a brief description of the IPS initiative. It then proceeds to frame the study theoretically using Foucault's notions of government, power and the subject before briefly describing the data collection methods. It then reports on and examines the interview data collected from two principals. This examination is organised around the specific practices of performativity and corporate managerialism that the principals engage in under the IPS regime. The analysis of the data reveals how power is inscribed in the selfsteering practices of principals, and how these self-steering techniques contribute to the formation of the neoliberal subject of government in the educational arena.

\section{The IPS initiative}

Up until 2009, the governance of the WA education system was highly centralised, with the education bureaucracy responsible for policy, recruitment, school finances, many aspects of management and the regulation of parental choice of schools. While there had been a few attempts at major decentralising reform prior to 2001, the devolution of responsibilities away from the central bureaucracy had been rather piecemeal. In the lead-up to the 2008 State election, the conservative Liberal-National Coalition announced an education reform agenda. The Empowering School Communities (Liberal Party of WA, 2008) policy represented a continuation of the trajectory of school self-governance and principal autonomy the Premier, Colin Barnett, began when he was Minister of Education a decade earlier. The policy's central feature was the establishment of 'a system of public schools 
where policy and budget will be determined for implementation locally, for those schools that are equipped to do so' (Liberal Party of WA, 2008). The policy sought a significant transformation to the governance of the public school system (Fitzgerald \& Rainnie, 2011). Its vision was to devolve greater decision-making authority to principals and school communities so that these groups could exercise choice and influence over decisions that affect their schools.

Following the Liberal Party's election victory in 2008, the Premier appointed as Minister of Education, Dr Elizabeth Constable, who was tasked with delivering the Empowering School Communities election promise. By mid-2009, Barnett and Constable jointly launched the IPS programme. Its discursive framing gave it wide appeal and legitimacy. It avoided the language of choice, markets and efficiency, which has often framed political and scholarly discourse about self-managing reform (Blackmore, Bigum, Hodgens, \& Laskey, 1996; Lingard, Hayes, \& Mills, 2000; Smyth, 1993). The Premier and Minister promoted IPS as a move to free principals from the 'suffocating red tape' of the bureaucracy 'that prevents imaginative leadership' (Barnett \& Constable, 2009). The programme's brochures described IPS as a move towards community and school empowerment, with schools enabled to 'shape their own future' (DOE, 2010). Schools selected for the programme through the application process would be given responsibility for recruiting and employing staff, managing their own one-line budget, creating and managing contracts and establishing a school board to oversee the school's management. They would also be regulated at a distance through mechanisms of accountability.

According to Fitzgerald and Rainnie (2011), IPS represents a political intervention into the education domain aimed at its re-regulation through the discourses of New Public Management. There is little research on the specific nature of this re-regulation as it bears upon the lives and practices of principals, whose work practices are arguably most affected by the policy. This article inquires into these work practices. A Foucauldian theoretical lens is used to examine how the subjectivities of two IPS principals are formed under the IPS regime through their employment of specific self-steering practices. In so doing, this article identifies the operation and effects of governmental power through individual selfgovernment, as it is exercised in the IPS regime. Before examining these practices, let us consider this study's theoretical framing.

\section{Power and the subject: a Foucauldian perspective}

This article utilises a number of concepts developed by Michel Foucault (1977, 2002, 2007, 2008) and Foucauldian scholarship. Foucault's notions of power, discipline, normalisation, government and subjectivity have made a significant contribution to education research (Peters et al., 2000; Popkewitz, 1996, 2000; Popkewitz \& Brennan, 1998). A large part of Foucault's studies are concerned with the constitution of the subject in society. For him, the 'subject' has two meanings: 'subject to someone else by control and dependence, and tied to his own identity by a conscience or self-knowledge' (Foucault, 2002, p. 331). The subject, Foucault argued, cannot be understood outside of the complex, strategical and tactical relations of power exercised in institutional, political and everyday life. Through his studies, Foucault illuminated the relationship between the subject, power, knowledge and truth: 
What I wanted to try to show was how the subject constituted itself, in one specific form or another, as a mad or a healthy subject, as a delinquent or nondelinquent subject, through practices that were also games of truth, practices of power, and so on. (Foucault, 1997, p. 290)

Foucault's examination of the exercise of power through historically contingent institutional knowledge and practices, such as examination, documentation and normalisation, rendered visible the practices of truth-making as a basis for constituting and regulating the individual (Foucault, 1977). These technologies of power exert an individualising and normalising effect on human beings, constituting individuals as certain kinds of subjects, such as 'criminal' or 'mad'. For Foucault, then, power 'categorizes the individual, marks him by his own individuality, attaches him to his own identity ... It is a form of power that makes individuals subjects' (Foucault, 2002, p. 331).

While offering a useful notion of subject formation through power and knowledge, there is a sense that Foucault had in his earlier studies 'investigated subjectivity primarily with a view to "docile bodies" and had too strongly stressed processes of discipline' (Lemke, 2002, p. 52). In those studies, power is primarily understood as investing the subject, and it 'is transmitted by them and through them; it exerts pressure upon them, just as they themselves, in their struggle against it, resist the grip it has on them' (Foucault, 1977, p. 27). Foucault acknowledges the limitation of his earlier conception, commenting later that he may have in his studies of the clinic and prison 'insisted too much on the technology of domination and power' (Foucault, 1997, p. 225). Foucault's work on government and ethics marks a theoretical shift related to his conception of power and its relation to the subject. This is evident in his genealogy of the modern state (Foucault, 2007, 2008), where he sketches the emergence of the art of government and governmental reason. Here, Foucault examines the rationalities and mechanisms concerned with the administration of groups (populations) and individuals conceptualised as 'free' to act in one way or another. In these studies, a notion of freedom enters more fully into Foucault's conception of power. In The Subject and Power (Foucault, 2002), power is understood as:

A set of actions on possible actions; it incites, it induces, it seduces, it makes easier or more difficult ... it is always a way of acting upon one or more acting subjects by virtue of their acting or being capable of action. A set of actions upon other actions. (Foucault, 2002, p. 341)

Foucault emphasises in these studies the freedom of the individual to constitute him/herself as certain kinds of subjects. They can do this through a 'whole range of practices that constitute, define, organize, and instrumentalize the strategies that individuals in their freedom can use in dealing with each other' (Foucault, 1997, p. 300), or indeed use in relation to him/herself.

Regarding this shift in focus, Foucault commented:

I would say that if I am now interested in how the subject constitutes itself in an active fashion through practices of the self, these practices are nevertheless not something invented by the individual himself. They are models that he finds in his 
culture and are produced, suggested, imposed upon him by his culture, his society, and his social group. (Foucault, 1997, p. 291)

Foucault's studies in governmentality provide a perspective for understanding these historically contingent 'models' informing the practices of the self in modern society. According to Foucault, governmentality entails the development and use of technologies for governing the population, and the deployment of techniques of the self. It therefore locates 'the ethics of the government of the self on the same plane as the government of others and the state' (Dean, 1994, p. 196). The identity of individuals is tied to patterns of social administration because governmental practices, the self-steering practices of individuals, are integral to how the subject actively constitutes him/herself as a healthy, useful and productive self-governing individual. Foucault explains an effect of this on our approach to understanding the subject:

I think that if one wants to analyze the genealogy of the subject in Western civilization, he has to take into account not only techniques of domination but also techniques of the self. Let's say: he has to take into account the interaction between those two types of techniques - techniques of domination and techniques of the self. He has to take into account the points where the technologies of domination of individuals over one another have recourse to processes by which the individual acts upon himself. And conversely, he has to take into account the points where the techniques of the self are integrated into structures of coercion and domination. The contact point, where the individuals are driven by others is tied to the way they conduct themselves, is what we can call, I think, government. Governing people, in the broad meaning of the word, governing people is not a way to force people to do what the governor wants; it is always a versatile equilibrium, with complementarity and conflicts between techniques which assure coercion and processes through which the self is constructed or modified by himself. (Foucault, 1993, pp. 203-204)

This article utilises these notions of the subject, power and government as analytical tools for examining the IPS programme. The IPS programme introduces a neoliberal regime of government and self-government into the school domain in WA. In so doing, it introduces new possibilities for principals to actively participate in practices of self-formation. This leads us to reflect on the discourses and practices through which individual principals selfsteer, exercise their freedom and govern themselves and their schools. This study locates a series of 'contact points' between neoliberal political rationalities, and the ways in which principals exercise their freedom in managing their schools, and their reflection on their activities. In so doing, this study renders visible how principals construct their subjectivities, and how these act as 'vehicles of power' (Foucault, 2002, p. 98), specifically by executing a shift from bureaucratically managed schools to the self-managing schools steered at a distance through mechanisms of accountability.

\section{Methods}

A consequence of theoretically framing the IPS programme in this way is that neoliberal reforms can be understood by examining the immediate and everyday practices where neoliberalism is realised, such as the utterances and practices of individuals. According to 
Ball and Olmedo (2013), neoliberalism " does us" - speaks and acts through our language, purposes, decisions and social relations' $(2013$, p. 88). The study reported on here uses semi-structured, face-to-face interviews with two principals of IP secondary schools to generate insight into how the principals engage with the IPS programme. These 'purposeful conversations' (Burgess, 1988) sought to generate in-depth and context-specific thick descriptions (Patton, 2002) around two key themes that structured the interviews: the principals' understandings of IPS (discursive framing) and how they were exercising their autonomy in this regime (practices). An inductive qualitative analysis (Patton, 2002) of the interview data was then undertaken. The objective of this analysis was not to produce generalizable observations about the reality of the IPS regime - the collection of data from only two principals makes such a task problematic. Rather, the purpose of the analysis was to identify evidence of the specific fashioning of the principals' subject positions as a result of the IPS initiative. This interview and analytical method enables a fine-grained analysis of the 'enactment' (Ball et al., 2012) of the IPS policy, or specifically, how the two principals positioned themselves through governmental-ethical practices of self-formation. The data has been grouped around three key sets of practices that emerged from the interviews, and which I have termed: managing performance, recruitment and employment, and leading the enterprise. The analysis that follows weaves together the interview data and the Foucauldian analytical tools described in the previous section.

\section{The interviews}

\section{The schools}

As the experiences of school reform are shaped by the context of enactment of policy (Ball et al., 2012), it is worth briefly describing some contextual features of each school. The first school, Sunshine High, has approximately 900 students from years 8 to 12. It services a community with a socio-economic index below the national mean with student achievement below the national average. The school has many discipline issues, but it also has a strong pastoral care programme. Bridgette has been a principal for more than a decade and has been principal of Sunshine High for about half of this period.

The second school, Westside High, is $20 \mathrm{~km}$ south of Sunshine High. It has approximately 1200 students from years 8 to 12 . Unlike Sunshine High, Westside High is a relatively new school with modern facilities. It also services a socio-economic area measured below the national average, but above Sunshine High. John is a newly appointed principal. The school's academic performance and attendance rates have improved over the past three years, with NAPLAN testing results now comparable to schools with a similar socio-economic background. Both principals were interviewed approximately six months into their first year as IPS schools. A follow-up interview with Bridgette in her school's second year was conducted. Westside High was entering its second year into the programme at the time of writing.

\section{Managing performance}

Both principals welcomed the opportunity for greater autonomy, responsibility and flexibility. Both believed that the DOE was inflexible, inefficient and unresponsive to their 
schools' needs. Bridgette said the Department often stifled her capacity to 'get things done', but on becoming an IPS principal she now had the autonomy and authority to make meaningful, efficient and effective decisions. Bridgette describes that she no longer has

one person who I have a direct relationship with in terms of performance management. I have been left in a lot of ways to be my own performance manager, which as a person with a lot of experience in education I am quite comfortable doing.

Although Bridgette construes herself as having greater autonomy, neoliberal programmes of autonomy are accompanied by 'technologies of performance' (Dean, 1999) that steer individual conduct at a distance. In the IPS programme, one of these technologies is the 'delivery performance agreement', a contract between the IPS principal and the Director General of the DOE. The contract is a technology of power that imposes 'compulsory visibility' (Foucault, 1977, p. 187) over each IP school's performance. It does this by translating political and bureaucratic goals into auditable targets (such as test results, attendance rates and financial data) that principals are held responsible for achieving. It induces 'practices of performativity' (Ball \& Olmedo, 2013), by subjecting principals to a performance review for every three years. So, Bridgette's characterisation of being 'her own performance manager' is not strictly true because she is performance-managed by the Director General and assessed against the performance contract. Nevertheless, Bridgette's description is revealing.

On the one hand, Bridgette's declaration that she is her 'own performance manager' reveals how the performance contract acts as a regulatory device of self-governance. The contract opens up for Bridgette a space for the practice of her freedom where she can inscribe her professional identity as a performance manager. Bridgette recognises that she cannot simply be the principal of her school. To be her 'own performance manager', she suggests, means being a decision-maker whose role it is to understand, manage and take responsibility for the performance and outcomes of her self, others and her school. Attaching herself to this identity evinces an effect of power operating through performance contracts in devolved school systems. The performance agreement indirectly acts on Bridgette's actions by inducing practices of performance monitoring, self-reflection and responsibility for her and others' performance. This is also the case for John who says the performance contract and the school's business plan is a 'mandate for us to reflect, to innovate, to assess, to change based upon meeting the outcomes of that document'. Insofar as Bridgette and John tether this form of self-conduct to their identities as responsible selfmanaging principals, the performance contract represents a form of power that attaches principals to corporate managerialist identities. It 'is a form of power that makes individuals subjects' (Foucault, 2002, p. 331) through rendering principals 'active in their own government' (Rose, 1999, p. 142).

On the other hand, Bridgette's description demonstrates that principals experience IPS and the performance contract as autonomising and empowering. The performance contract is one mechanism that facilitates this perception. As a self-steering mechanism, the performance contract establishes for its subjects 'a certain entrepreneurial form of relationship to themselves as a condition of their effectiveness' (Du Gay, 2000, p. 65). It 
does this by specifying key performance indicators, which steer principals' conduct to valued outcomes, however, how these outcomes are to be achieved is not prescribed.

Consequently, principals are 'empowered' to be 'autonomous choosers' (Peters et al., 2000, p. 120) in response to their local context. For example, while Bridgette and John speak of using standardised NAPLAN results, graduation, attendance and suspension statistics, and financial audits as key measures of their performance, John remarks that principals can position themselves in relation to their practice and objectives between two poles: 'you can be as entrepreneurial and as conservative as you like'. So, while the performance contract disciplines John and Bridgette through stipulating objectives and tying these to their professional identities, it also positions them as potential entrepreneurs of their selves and their schools. The practices through which John develops an entrepreneurial relation to himself and his school are considered below.

\section{Recruiting and employing}

The governmental benefit of this 'steering at a distance' is that it provides sufficient flexibility for principals to manage their schools and to do so in the light of their local contexts. Both principals perceived the capacity to recruit and employ staff as essential to managing performance and improving school and learning outcomes. This appears to be one of the most appealing features of the IPS initiative. Bridgette explained that the previous centrally determined placement system had resulted in her school 'three years ago having a large number of fixed-term teachers who weren't very good teachers, and our data wasn't very good'. The authority granted to principals by IPS over the recruitment and employment process gave Bridgette and John power over achieving their KPIs through shaping the quality of teaching and student learning in their schools, specifically by employing staff in response to local needs. Both principals explained that they judged candidates according to their perceived fit with the local context of the school. John believed it important to 'handpick' candidates that 'support our ethos, what the culture is, understand the vision, know what we are about, what we are trying to achieve', as described in the school's business plan and prospectus. Bridgette had recently organised some candidates to deliver short demonstration lessons with a group of students. She observed how this enabled the selection panel to judge the suitability of the candidates, and particularly their ability to build rapport with the school's students. It is at this level of practice that power is exercised. As Foucault argues, power 'operates on the field of possibilities in which the behavior of active subjects is able to inscribe itself' (Foucault, 2002, p. 341). By setting up the recruitment processes, engaging in the practices of recruiting, and making judgements based upon norms of 'what makes a good teacher in this context', Bridgette and John form their subject positions as 'responsible self-managing principals'.

Neoliberalism is marked by its cultivation and normalisation of entrepreneurial and competitive attitudes, dispositions and capacities. School-based recruitment practices enabled John to construct himself as an entrepreneurial principal. He described how he sought to exercise his flexibility to employ staff by seeking to recruit teachers from outside of WA. He declared that when it comes to staffing, '. . . it is a competitive market and you are trying to get the best people'. For John, the labour market is competitive and global, so he sought to exercise his entrepreneurial freedom beyond the borders of Australia: 
I had discussions with a visa broker in Bayside City and he brings workers over from around the world, brokers their visa and places them in jobs. I wanted him to do that for me in my school. We have been getting lots of applications from Ireland, England, Canada because the jobs just aren't there and these are high-quality teachers but they can't get work because their economies have shrunk. Well, I wanted him to broker their jobs for these teachers, he covers all of their costs, doesn't cost me a cent ... da da da, they sign up and they land at my school for two years on their visa. I've got them for two years, after that they can go seek work elsewhere...

Construing his school as an enterprise competing for a limited supply of 'quality' teachers, John uses IPS as an opportunity to exercise his freedom to improve his school's outcomes by exploring labour opportunities from outside of Australia. In the process, John promotes to potential employees his school's ICT facilities, smaller class sizes and the school's improved test results. Such practices evince the inscription of neoliberal governmentalities in the selfgovernment of the IPS principal. Although the DOE considered recruiting outside of Australia too politically risky to support, John uses the employment flexibilities of the IPS programme to define and enact a neoliberal ethics of the self that embodies 'the presupposition that humans are, could be, or should be enterprising individuals, striving for fulfillment, excellence, and achievement' (Rose, 1996, p. 154).

Even problems related to recruitment and employment were an opportunity to cultivate a managerial ethic. Whilst Bridgette positions herself as a flexible and effective principal, she expressed that she is constrained by new administrative burdens, particularly those related to employing staff (Gobby, 2013). Similar to the experiences of school leaders in Starr's (1998) study, Bridgette felt 'tied to the office' because she was doing 'a whole lot of paper work, making sure I've dotted my i's and crossed my t's and covered my back'. Bridgette considered hiring more administration staff to solve the problems associated with the school's increased administrative burden, but her capacity to employ more support staff was constrained by the school's facilities:

Look, the biggest issue is . . . to take on more responsibility I need more support staff. To have more support staff I need more facilities; that I have no control over. That is always political. So, I am stuck. So, although I have autonomy to do some things, I haven't got the infrastructure to do it.

This constrained her ability to engage in the practices that would enable her to lead educationally by, for example, getting 'out into the classroom to actually work with staff'. Interestingly, Bridgette then commented: '. . . I guess that's my reflection and that's something I need to manage'. Here, Bridgette speaks the discourse of performativity. This steers her towards managerialist reflections and responses that also responsiblise her for problems related to resources and staffing. This demonstrates an effect of the accountability regime, such as the performance contract, as a technology of power: 'to induce ... a conscious and permanent visibility that assures the automatic functioning of power' (Foucault, 1977, p. 201). Hence, rather than blaming external factors for the effects created by a lack of resources, Bridgette instead assesses her own conduct and attitude in terms of her managerial effectiveness and how it can be improved. 


\section{Leading the enterprise}

While IPS affords principals greater latitude to make decisions, it also renders principals responsible for school management and outcomes. Bridgette's experience highlights it is not always possible for principals to exercise the scope of their authority because of external factors. Nevertheless, decentralisation enjoins principals to think and act innovatively about the local problems and constraints that their schools face. This is a result of the shift away from the administrative and process-driven principal associated with the 'rule governed patterns of certainty and control' of centralised education systems (Popkewitz, 2000, p. 20). Neoliberal government incites and induces new ways of being and becoming in the education domain. This is a way of being that accepts uncertainty, flexibility, resource constraint and competitive enterprise as the new norm (Du Gay, 1996). As a consequence, the 'teacher is assumed to possess a pragmatic individuality that is tied to the contingencies of situations in which problems arise' (Popkewitz, 2000, p. 21). John's conduct and attitude illustrate how IPS supports the cultivation of the neoliberal problem-solving professional in the education domain.

While Westside High experienced administrative burden, for John, this was part and parcel of him being accorded managerial freedom. John believed there are always constraints to managing 'but you're only limited by your creativity and your ability to bend things the way you want it to work'. John addressed his school's increased workload by making efficiency gains and creating new income streams in order to employ more staff. To do this, John had recently outsourced to private companies the school's uniform shop, the school's Information Technology supply and maintenance and the school's café. In relation to the uniform shop and café, John sought to use this outsourcing to generate income through commissions, which the Department eventually supported, which indicated their loosening of control over school matters:

Under the old agreement you charge them a lease fee and that's it. And I was saying [to the Department] they're going to make a lot of money, they're prepared to pay me a commission to come into the school. That money can then go back into the school, for the kids, where's the problem with that? And they were 'Oh, oh, well, well, oh', so they talked it over at a meeting up there and they said, 'Yeah, fair enough, you can'.

Consonant with neoliberal governmentalities, John conceptualises himself as a CEO and his school as a small private enterprise: 'I run the school like a business, the students are our clients, my shareholders. It's a business'. Neoliberalism inserts itself into John's reflections and actions, guiding him to exercise his freedom as a self-responsible, flexible, innovative and utility-maximising professional (Simons, 2002; Thomson, 2009). IPS enables him to construe his students as a captive market and therefore an attractive commercial opportunity that could generate additional income to support the school's administration and its teaching and learning objectives. If to govern 'is to structure the possible field of action of others' (Foucault, 2002, p. 341), then power enters into the life of John's school through the corporate managerialist discourses that provide the tools for his selfgovernment. The IPS regime gives John the tools and legitimacy to position himself as an 
entrepreneur who views and conducts himself as the CEO of his school. These practices enable John to subjectify himself as an exemplary principal 'who embodies pragmatic capabilities and dispositions' (Popkewitz, 1996, p. 40; emphasis in original).

There is a moral dimension to John's entrepreneurial attitude and conduct. This surfaces when he is prompted in the interview to consider how external factors impact on his school and other IP schools. Rather than recognising that some schools face problems of external factors beyond their control, John suggests that problems faced by schools like Sunshine High are in large part related to a failure of the principal to innovate and be self-reliant. When pressed on this issue, he was reticent about acknowledging that the problem-solving opportunities of his school were different from other schools, for instance, those schools with ageing facilities or with fewer student enrolments and therefore less income. He instead claimed that:

IPS has helped to support that but if you need IPS to make your school work then you are not doing your job. It's an enabler but you've got standards, you've got expectations of what you should be doing, you have the AITSL standards, what the principal should be.

Here, John sheets home responsibility for solving the problems schools face to principals, who must improve outcomes by harnessing their school's available resources, whether or not those resources are equitably distributed in the first place. Principals, he said, cannot be 'the sort of person who needs to know there is someone there all the time that you are in contact with'. He implies that there are harmful effects of relying on the state, in the form of the bureaucracy. As O'Malley points out, the prudent subject of risk produced by neoliberal governmentalities requires citizens to have a non-dependent relationship to the state because, 'To rely on the state to deal with the harmful effects of known, calculable and individually manageable risks appears feckless and culpable' (O'Malley, 1996, p. 202). Similarly, John contrasts himself to an image of a 'dependent' principal. He uses this reflection on other principals to inscribe his own identity as an innovative, entrepreneurial and effective leader. Through crafting a professional identity that is independent, innovative, self-reliant, and active in his self-government, John makes himself a prudent subject of neoliberal government.

\section{Conclusion}

The IPS programme in WA has been promoted using the rhetoric of empowerment, autonomy and independence. In spite of this rhetoric, IPS is best thought of as a programme of neoliberal government that introduces new regulatory mechanisms into the management of schools. Neoliberal government constructs 'the legal, institutional and cultural conditions that will enable an artificial competitive game of entrepreneurial conduct to be played to best effect' (Burchell, 1996, p. 27). It is suggested that that the unpredictability and rapid changes in the economic, political and social environment means that public enterprises must become more flexible and enterprising if they are to survive and thrive (Du Gay, 1996).Within this broad context, IPS reforms seek to govern schools as 'independent' public schools that are increasingly self-managed, innovative, responsive to their communities and 
competitive. To achieve this objective, IPS works on the conduct of principals by offering them greater choice and decision-making authority.

To prevent IPS being understood as an innovation that merely frees and empowers principals, this article has sought to highlight the governmental practices of self-formation that principals within the IPS regime engage. This analysis has been undertaken using Foucault's notions of power, government and the subject. This Foucauldian approach was taken because subjectivity is central to governing populations through individuals and therefore examining the practices of self-formation of individuals garners insights into the operation of contemporary forms of power. It enables a focus on governmental mechanisms and practices that depend on, harness and shape individual autonomy to achieve political and governmental ends. Specifically, this study contributes to our understanding of how school self-management functions as a regime of government and self-government through which power is exercised on, through and by principals. It illustrates how IPS enables two principals to self-govern in ways consistent with neoliberal governmentalities. Both principals were guided to varying degrees by the rationalities, mechanisms and practices of performativity and corporate management that are associated with neoliberal reforms. Both principals used the performance agreement and the practices of recruitment and employment to construe and act upon themselves as self-responsible professionals of selfmanaging schools. John used the affordances of the IPS programme to engage in the practices of corporate management, such as outsourcing, to cultivate his entrepreneurial self as a CEO, which he viewed as compatible with being a responsible principal.

It has not been the purpose of this article to provide a comprehensive account of IPS. Rather, it offers a perspective of it through the analysis of interviews conducted with two principals. Nevertheless, the Foucauldian approach of this article has drawn attention to the power inscribed in the self-steering practices of these principals and has shown how individual freedom is instrumentalised to governmental ends. In so doing, the analysis has shown how specific self-steering techniques and rationalities associated with IPS are contributing to the formation of the neoliberal subject of government in education today.

\section{Acknowledgements}

The author would like to acknowledge and thank Professor Barry Down and the anonymous reviewers for their helpful and constructive feedback on earlier versions of this article.

\section{References}

Ball, S. (2006). Education policy and social class: The selected works of Stephen J Ball. Oxon: Routledge.

Ball, S.J. (2007). Education PLC: Understanding private sector participation in public sector education. Oxon: Routledge.

Ball, S., MacGuire, M., \& Braun, A. (2012). How do schools do policy? Policy enactments in secondary schools. London: Routledge. 
Ball, S., \& Olmedo, A. (2013). Care of the self, resistance and subjectivity under neoliberal governmentalities. Critical Studies in Education, 54(1), 85-96.

Blackmore, J., Bigum, C., Hodgens, J., \& Laskey, L. (1996). Managed change and self management in schools of the future. Leading and Managing, 2(3), 195-220.

Burchell, G. (1996). Liberal government and techniques of the self. In A. Barry, T. Osborne, \& N. Rose (Eds.), Foucault and political reason: Liberalism, neo-liberalism and rationalities of government (pp. 19-36). London: UCL Press.

Burchell, G., Gordon, C., \& Miller, P. (Eds.). (1991). The Foucault effect: Studies in governmentality. Chicago, IL: University of Chicago Press.

Burgess, R. (1988). Conversations with a purpose: The ethnographic interview in education research. Studies in Qualitative Methodology, 1, 137-155.

Campbell, C., Proctor, H., \& Sherington, G. (2009). School choice: How parents negotiate the school market in Australia. Crows Nest: Allen \& Unwin.

Dean, M. (1994). Critical and effective histories: Foucault's methods and historical sociology. London: Routledge.

Dean, M. (1999). Governmentality: Power and rule in modern society. London: Sage Publications.

Department of Education. (2010). Unlock your school's future: Information for principals and school councils. Perth: Western Australian Department of Education.

Du Gay, P. (1996). Organizing identity: Entrepreneurial governance and public management. In S. Hall \& P. Du Gay (Eds.), Questions of cultural identity (pp. 151-169). London: Sage.

Du Gay, P. (2000). Entrepreneurial governance and public management: The antibureaucrats. In J. Clarke, S. Gewirtz, \& E. McLaughlin (Eds.), New managerialism new welfare? (pp. 62-81). London: Open University Press.

Fitzgerald, S., \& Rainnie, A. (2011). Putting the public first? An examination of the implications of the 2009 EAC report. Part two: Independent public schools. Perth: Curtin Graduate School of Business.

Foucault, M. (1977). Discipline and punish: The birth of the prison. London: Penguin Books.

Foucault, M. (1993). About the beginning of the hermeneutics of the self. Transcription of two lectures in Dartmouth on 17 and 24 November 1980 (ed. M. Blasius). Political Theory, 21(2), 198-227.

Foucault, M. (1997). Ethics, subjectivity and truth. The essential works of Michel Foucault, 1954-1984 (Vol. 1). New York, NY: The New Press. 
Foucault, M. (2002). The subject and power. In J.D. Faubion (Ed.), Essential works of Foucault, 1954-1984, Volume 1: Power (pp. 326-348). London: Penguin Books.

Foucault, M. (2007). Security, territory, population: Lectures at the college De France 19771978. Hampshire: Palgrave MacMillan.

Foucault, M. (2008). The birth of biopolitics: Lectures at the college De France 1978-1979. Hampshire: Palgrave MacMillan.

Gewirtz, S. (2002). The managerial school: Post-welfarism and social justice in education. London: Routledge.

Gobby, B. (2013). Enacting the Independent Public Schools program in Western Australia. Issues in Educational Research, 23(1), 19-34.

Government Media Office. (2009, August). New era for public education in Western Australia. Media Release. Retrieved from http://www.mediastatements.wa.gov.au/Pages/StatementDetails.aspx?Statld=1500\&listNa me=StatementsBarnett

Lemke, T. (2002). Foucault, governmentality, and critique. Rethinking Marxism: A Journal of Economics, Culture \& Society, 14(3), 49-64.

Liberal Party of WA (2008). Empowering school communities. Retrieved from http://www.platowa.com/documents/WA_Election_2008/Liberals/Empower.html

Lingard, B., Hayes, D., \& Mills, M. (2000). Developments in school-based management: The specific case of Queensland, Australia. Journal of Educational Administration, 40(1), 6-30.

Niesche, R. (2012). Foucault, counter-conduct and school leadership as a form of political subjectivity. Journal of Educational Administration and History, 45(2), 144-158.

O'Malley, P. (1996). Risk and responsibility. In A. Barry, T. Osborne, \& N. Rose (Eds.), Foucault and political reason: Liberalism, neo-liberalism and rationalities of government (pp. 189-207). London: UCL Press.

Patton, M. (2002). Qualitative research and evaluation methods (3rd ed.). Thousand Oaks, CA: Sage Publications.

Peters, M., Marshall, J., \& Fitzsimons, P. (2000). Managerialism and education policy in a global context: Foucault, neoliberalism, and the doctrine of self-management. In N.C. Burbles \& C.A.Torres (Eds.), Globalization and education (pp. 200-220). New York, NY: Routledge.

Popkewitz, T. (1996). Rethinking decentralization and state/civil society distinctions: The state as a problematic of governing. Journal of Education Policy, 11(1), 27-51. 
Popkewitz, T. (2000). The denial of change in educational change: Systems of ideas in the construction of national policy and evaluation. Educational Researcher, 29(2), 17-29.

Popkewitz, T., \& Brennan, M. (1998). Restructuring of social and political theory in education: Foucault and a social epistemology of school practices. In S. Popkewitz \& M. Brennan (Eds.), Foucault's challenge: Discourse, knowledge, and power in education (pp. 335). New York, NY: Teachers College Press.

Reay, D. (1998). Setting the agenda: The growing impact of market forces on pupil grouping in British secondary schools. Journal of Curriculum Studies, 30(5), 545-558.

Rose, N. (1996). Inventing our selves: Psychology, power and personhood. Cambridge: Cambridge University Press.

Rose, N. (1999). Powers of freedom: Reframing political thought. Cambridge: Cambridge University Press.

Simons, M. (2002). Governmentality, education and quality management: Toward a critique of the permanent economic tribunal. Zeitschrift Fur Erziehungswissenschaft, 5(4), 617-633.

Smyth, J. (Ed.). (1993). A socially critical view of the self-managing school. London: The Falmer Press.

Starr, K. (1998). Power and production in site-based management: The responses of women principals to structural reform in South Australian education. South Australian Educational Leader, 9(4), 1-12.

Thomson, P. (2009). School leadership: Heads on the block. London: Routledge.

Whitty, G., Power, S., \& Halpin, D. (1998). Devolution and choice in education: The school, the state and the market. Buckingham: Open University Press. 